\title{
EDITORIAL
}

\section{El desierto costero de Taltal: ¿oportunidades para el desarrollo agropecuario o la conservación biológica?}

\author{
The coastal desert of Taltal: An opportunity for agriculture development or \\ biological conservation?
}

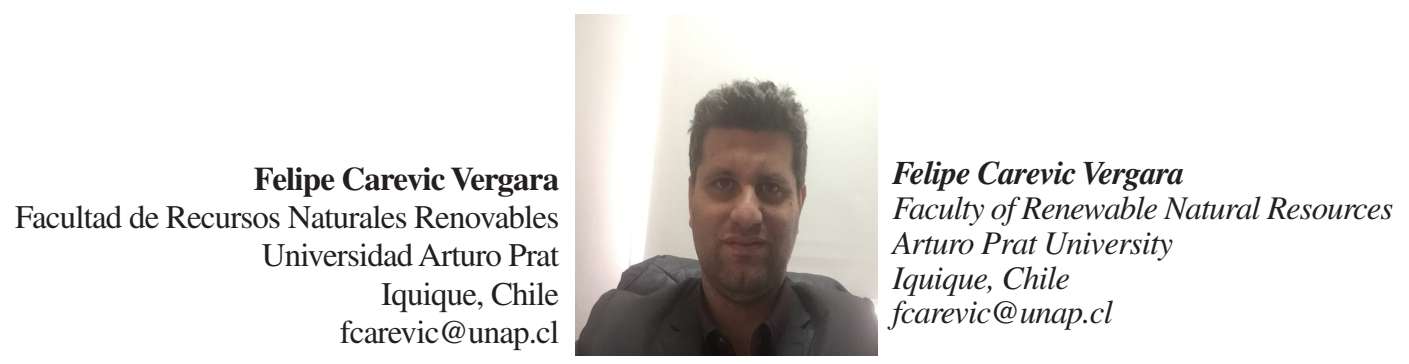

El desierto costero de Taltal observable en su máxima expresión biológica entre Taltal y Paposo, es hoy en día un foco incipiente de atracción turística a micro escala principalmente por la presencia de abundante flora, la cual se estima que está compuesta por alrededor de 250 especies de las cuales al menos un $65 \%$ es endémica y en algunos casos clasificadas como especies con problemas de conservación. Sin embargo, a nivel científico son escasos los estudios que se han llevado a cabo en estas especies, las cuales comprenden géneros de vegetales tan importantes a nivel agrícola y gastronómico como Stevia, Salvia o Solanum. En este sentido, las mayores actividades científicas en la zona, se han enfocado en proyectos de restauración de poblaciones de especies botánicas en peligro de extinción o en el monitoreo fisiológico de estos mismos individuos, por lo que la puerta científica ha quedado abierta para el estudio real de la posible potencialidad de estos géneros de plantas anteriormente mencionados a nivel agrícola. Cabe mencionar que la distribución de estas especies vegetales en esta zona, se debe en gran medida a la periódica presencia de bancos de niebla, lo que genera un ecosistema compuesto además por especies de fauna nativa representativas, tales como guanacos (Lama guanicoe), anfibios (Rhinella atacamensis) y pinguinos (Spheniscus humboldti), y otros de carácter introducido tales como burros, ovejas, caballos y liebres, los cuales suelen pastorear libremente en las quebradas adyacentes a Paposo. A nivel agrícola,
The coastal desert of Taltal, whose maximum expression is found from Taltal to Paposo in northern Chile, is currently an incipientfocus of small-scale tourist attraction mainly due to the presence of abundant flora. This is estimated to be composed of about 250 species, of which at least $65 \%$ are endemi, and in some cases are classified as species with conservation problems. Few scientific studies have been performed with these species, which include important agricultural and gastronomical genera such as Stevia, Salvia and Solanum. Most scientific activity in the area has been focused on the restoration of plant species in danger of extinction and on physiological monitoring of these species; thus the agricultural potential of the species in this desert is still an open scientific question. It must be noted that the distribution of plant species in this area is closely related to the periodic presence of heavy fog banks ("camanchaca"). The ecosystem also includes native fauna such as the guanaco (Lama guanicoe), the amphibian Rhinella atacamensis and even a penguin (Spheniscus humboldti), along with introduced species including donkeys, sheep, horses and hares, which graze freely in the canyons near Paposo.

The area has an interesting focus for agriculture not currently developed; there are isolated olive plantations and a few vegetables. There are some projects financed by FIA/FIC being developed in the El Hueso and La China canyons using fogcatchers to provide water to generate irrigation 
la zona presenta un interesante foco de desarrollo aún no explotado, debido a la presencia de aislados cultivos de olivos y algunas hortalizas, en donde se destacan algunos proyectos financiados por FIA/ FIC y desarrollados en las quebradas El Hueso o La Cachina relacionados con el aprovechamiento de agua mediante atrapanieblas para generar sistemas de riego en este tipo de cultivos. En este mismo sentido, otros proyectos financiados con aportes principalmente de la Municipalidad de Taltal, se relacionan directamente con el desarrollo de la agricultura urbana y el establecimiento de especies xerofíticas y frutales en áreas verdes de la comuna. Otros cultivos como la Salicornia o el espárrago están actualmente pensados a futuro como soluciones innovadoras, basados principalmente en su implementación bajo los principios de la agricultura del desierto, especialmente en lo referente a eficiencia hídrica de riego. Bajo este escenario, cabe preguntarse si esta zona presenta reales oportunidades para un desarrollo agrícola o bien se debe priorizar la generación de programas de conservación biológica de sus especies vegetales para el aprovechamiento del turismo de intereses especiales. En el caso de la agricultura, el principal obstáculo es el acceso al recurso hídrico y la escasa innovación en la incorporación de nuevas especies agrícolas que requieran una tasa menor de riego que los olivos, los cuales son el eje productivo actual de Taltal, especialmente en materia de aceites. No obstante, el tipo de suelo y las temperaturas medias anuales afloran como aliados benignos al momento de implementar estrategias agrícolas en la zona. En el caso de la conservación de la biodiversidad de esta verdadera "isla biológica", un obstáculo insoslayable es la privatización de los terrenos en donde crecen muchas de estas especies vegetales en peligro, lo cual complica de cierta manera la creación de una reserva o área protegida en las cercanías de Paposo o Taltal, quedando como recurso viable el hecho de proteger la biodiversidad presente en la Quebrada de Miguel Díaz ubicada a 50 kilómetros al norte de Paposo, en la cual CONAF centra sus estrategias actuales de conservación. Sin lugar a dudas, el mayor beneficio que conllevará la protección de la biodiversidad de la zona se relaciona con la implementación de rutas turísticas de intereses especiales y prioritariamente en el aumento de individuos vegetales que estén categorizados como en peligro de extinción tales como Dalea azurea, Dicliptera paposana o Croton chilensis mediante conservación in situ. for this kind of culture. Other projects financed mainly by the Municipality of Taltal are directly related to the development of urban agriculture and establishment of xerophyte and fruit species in the green areas of the city. Innovative solutions using Salicornia and asparagus are being considered; their implementation is mainly based on the principles of desert agriculture, especially irrigation efficiency. It is worth asking if this zone has real opportunities for agricultural development, or if priority should be given to programs of biological conservation of native species to take advantage of specialty tourism. The main obstacle to agriculture is access to water and the little innovation in incorporating new species that require less irrigation than olives, which are currently the productive axis of Taltal, especially olive oil. The soil type and mean annual temperature are benign allies for implementing agricultural strategies in the area. An unavoidable obstacle to the conservation of biodiversity in this "biological island" is the privatization of the areas where many of these endangered species live, which complicates the creation of a reserve or protected area near Paposo or Taltal. A viable alternative is to protect the biodiversity present in the Miguel Díaz canyon, located $50 \mathrm{~km}$ north of Paposo, where the national forestry corporation (CONAF) currently concentrates its conservation strategy. Undoubtedly, the greatest benefit that the protection of the biodiversity of the zone will entail is related to the implementation of special interest tourist routes, which should put priority on increasing the numbers of the species in danger of extinction such as Dalea azurea, Dicliptera paposana and Croton chilensis with in situ conservation. 